\title{
A REFLECTION OF AN EFFECTIVE ASSESSMENT PRACTICE IN THE BACHELOR OF CONSTRUCTION PROGRAMME: AN EXPERIENTIAL LEARNING CASE STUDY IN NEW ZEALAND
}

\author{
Don Amila Sajeevan Samarasinghe
}

\section{INTRODUCTION}

The Bachelor of Construction in Otago Polytechnic Auckland International Campus is a rapidly growing programme, with New Zealand domestic students and many other students from a variety of countries including, China, Hungary, India, Korea, Malaysia, Philippines, Russia, South Africa, Thailand UK and USA. It is experiencing very high levels of growth and addresses a significant need in the New Zealand construction sector. My team and I are involved in a significant initiative targeted specifically at changing traditional assessment practices to effective assessments that promote learning. The fundamental principle of our learning and teaching model is experiential learning and reflective practice. We are in the process of redesigning the courses to merge key skills and knowledge with learner capability. The project described in this paper set out to provide learning opportunities for students through effective assessment processes.

\section{BACKGROUND}

Assessments are an integral part of the education process. The assessments designed to encourage learning promote a student-led approach to learning or assessment for learning (AfL). As suggested by the Assessment Reform Group (1995), the learning tools should be designed from teaching and learning perspectives. When the assessments are introduced, the learning goals should be shared with the students. The students should then be able to gauge these and set goals for achievement. The six principles of assessment for learning developed by Sambell, McDowell, and Montgomery (2013) show that having authentic and complex assessment tasks promotes a student-led approach to learning. In this process, the class facilitator's role is to encourage and support students to try out their learning, practice and improve, build competence and confidence through in-class formative assessments before they are summatively assessed. Subsequently, students would receive opportunities to learn through assessments rather than evaluation based on their learning. Marking on-going assessment and record-keeping are key parts of the assessment process. Some good practices of assessing and providing feedback include daily assessment, providing timely feedback to students and record-keeping for facilitators. Meaningful constructive feedback on assessments are helpful so that students can feed forward in their learning journey. Moreover, incorporation of active and collaborative discussion during the assessment feedback session would benefit both students and facilitator to sharpen their learning through collaborative discussions. Past literature showed that as a way of an effective assessment practice, sustainable assessments should be encouraged (e.g. self-assessment) during the lifelong learning process. 
In sustainable assessments, it is crucial to balance formative and summative tasks so that the assessing process would support and encourage learning as opposed to just measuring student work (Nguyen \& Walker, 20I4). Formative use of summative tests promote students to engage in a reflective review of the work they have done and it enables them to prepare their revision effectively. When assessment feedback are provided, it is important to identify what has been done well by the student and what still needs improvement and give guidance on how the student can make that improvement. Also, opportunities for students to follow up on comments should be planned (Black, Harrison, Lee, Marshall, \&Wiliam, 2003). As a result, the feedback would become sustainable for leaners when they support students to independently self-monitor their work and feed forward in students' future learning activities (Carless, Salter,Yang, \& Lam, 201 I).The assessment practices developed by Black, Harrison, and Lee (2007) showed that peer and self-assessment are some of the critical characteristics of sustainable assessment practices.

Peer and self-assessments are good teaching practices which also make unique contributions to the development of student learning (Carless, Salter,Yang, \& Lam, 20I I). However, in peer and self-assessments, assessment evaluation criteria should be made transparent to students. Concrete examples and modelling exercises should be provided by the facilitator to develop student understanding of peer and self-assessments. In addition, teaching the habits and skills of collaboration in peer-assessments (Sambell, McDowell, \& Montgomery, 20I3) would help students to apply peer-assessments in their experiences.

\section{THE ASSESSMENT}

This case study is based on an innovative summative assessment conducted in the bachelor of construction programme offered at Otago Polytechnic Auckland International Campus. It primarily aimed to assess students' understanding of typical construction elements, such as: foundations, framing, fixings and envelope, and non-specific bracings used in small buildings in New Zealand. As the class facilitator, I guided and supported students to achieve the learning outcomes through a video production project based on an ongoing residential construction site visit. In addition, this assessment also aimed students to develop their capabilities such as effective communication skills, team-working skills, reflective practices, practicing health and safety and demonstrating digital competence (Lei, 2016). It is important to mention that potential ethical issues were managed throughout this assessment experience.

\section{PREPARATION THROUGH AN ICEBREAKING TASK}

Ingalls (20|8) found that teamwork activities support groups to learn and perform at a higher level as it integrates learning skills from every team member. Therefore, as an assessment preparation task, we conducted a "Spaghetti Marshmallow Challenge" group activity to build up teams and identify the strengths and weaknesses of different students. After this activity, students established their group leaders. Students' active participation in group discussions increased as they felt involved and respected after this icebreaker activity (Brookfield, 1995).

The increased participation helped to make the assessment process robust and efficient for every group member. Also, understanding the qualities of peers helped in constructive and critical peer and self-assessment process that was a part of the group assessments (Moon, 2004). Also, this icebreaking task contributed to increase the inclusiveness in the classroom. Students experienced equality through their participation. The various roles they assigned in the group, promoted the partnership between group members. Eventually, the groups worked as teams acknowledging the strengths and weaknesses of their team members. Therefore, I believe this was a great opportunity for students to practice the "participation" principle of the Treaty of Waitangi (Bell, Kawharu,Taylor, \& Belgrave, 20 17). The skills gained such as leadership, communication and participation, from Spaghetti Marshmallow Challenge were then transferred into the main assessment. 
Also students and I then worked on making links between assessment questions and the site visit. As discussed by Vassilakis (20I0), clear communication enabled students to understand assessment requirements. We analysed the site in terms of its location, zone, underground building services and regulatory environment using Google Maps and GeoMaps tools. We also carefully went through architectural drawings and structural drawings to understand the types of construction systems used in the building that we were going to visit. I found that sometimes it was challenging to explain the assessment requirements as students were not able to understand how to apply assessment questions in the case study context. After analysing this issue, I found this was because many international students came from passive learning environments in which they were assessed based on examinations rather than student-centred assessments such as case study presentations. Therefore, as suggested by Elen, Clarebout, Leonard and Lowyck (20I4), I discussed with my students their former passive learning style and the importance of transforming to an active learning style to suit in student-centred class environment in New Zeland. The groups consisted of students from different countries and age groups. Therefore, while preparing and organising transport for the site visit, students learnt to listen to others and respect other cultures. I believe that this experience has helped to create a cultural shift in students' thinking, learning and behaviour. This made me realised that my approach of grouping students had been influenced by a workshop that I participated on principles of co-operating learning conducted by AKO Aotearoa in 2017.

My previous experiences have taught me that conducting site visits without assigning responsibilities to students may not be successful. Often, students tend to visit and observe construction activities as opposed to reflecting on what they observed and making links between observations and their learning. However, Burt, Donaldson, Hruska, Hinch, and Richardson (20I2) discussed that sufficient preparation before filed visits would help to achieve relevant learning outcomes. Therefore, I created a checklist and to-do-activities for students to achieve the learning outcomes in their assessment (Lohmann, 1980), with this checklist, the mutual understandings and expectations between the facilitator and students will be improved to make the experience meaningful and positive.

\section{THE CONSTRUCTION SITE VISIT}

Students were given copies of the architectural and structural drawings prior to visiting the site. During the site visit, they referred to the drawings and understood similarities and differences between drawings and real construction activities. I felt many students faced difficulties with reading and interpreting the drawings. Students kept asking me to interpret the meaning behind the various sections in the drawings. This indicated to me that I need to use more real construction drawings in my class activities to help students to be more familiar with reading building drawings. During this visit, students observed wall frame elements and building system installation processes. They discussed their questions with the site manager and me. As a part of the assessment activity, students recorded (written notes, audio recording and video recording) their observations and findings in order to use in their summative assessment.

I observed that students needed more self-awareness regarding safety precautions while on construction sites. This experience taught me that there was more room for me to further promote students' engagement and provide support to make stronger links between theory and practice (Faria \& Chagas, 20I3). For example, the health and safety requirements outlined in the Health and Safety Act 20 I5, should be applied for future construction site visits.

Interestingly, this learning activity was facilitated by one of my graduates. I found that having our graduates as industry representatives, greatly increased access to the industry as my graduates helped me to visit their construction sites. Also, it was very inspiring and influential for current students to help reach their goals. I felt proud and satisfied to see my graduates sharing their journey and experiences with my current students. This experience made a huge mental shift in my students to become more confident in believing that they will also manage construction sites in the future just like their seniors (McLelland, McKenna, \& French, 20I3). In addition, the feedback received from my graduate greatly helped me to develop my own teaching practice. 


\section{REFLECTIVE SESSION}

As suggested by Moon (2004), we performed a group reflective activity consisting of two effective learning methods called experiential learning and reflective learning. Students reflected on what they observed during the site visit and asked questions on unclear points. It was apparent that students had difficulties in reading and interpreting building drawings. They discussed that sometimes it was difficult to visualise what is on the drawings in reality. This reflection provided many opportunities for us to share our findings among group members. However, it did not give opportunities for different groups to listen to the findings of other groups. Therefore, I think it would have been better if I had asked students to share their findings with other groups as well. This would have created some meaningful critical conversations between groups that would have led them to generating the best assessment content for all groups.

Followed by the above reflective activity, students worked on creating a 30 minute group video based on the site visit experience and their knowledge. Students used the breakout rooms allocated for research activities to work on their video preparation. I remembered that I was amazed by seeing how students referred to their previous class notes to make mind maps to outline the video content. I found that I was very keen towards observing and reviewing my students' video preparation process. I found students worked well in the small breakout rooms. Students said that they found the small breakout rooms with triangular whiteboards were very resourceful for self-directed learning sessions. I participated in their group conversations and provided feedback on their work. I would say that it was very satisfying to see the passion in students during their learning and assessment preparation tasks.

The latter part of this group activity was to complete a reflective report by critically reviewing the completed group work process and outcomes based on personal experiences. Students were asked to evaluate themselves and their peers in terms of the effectiveness (contribution, responsibility, and commitment) at the site and while preparing the video. After evaluating the reflective reports, I felt that the students did not clearly understand what reflection actually meant. A majority of students had just listed what happened instead of analysing their experiences to plan actions that could be applied in the future (Jasper, Freshwater, \& Rolfe, $201 \mathrm{I}$ ). Therefore, based on my self-reflection I decided to conduct personal interviews with students as a reflective activity to understand the effectiveness of this group assessment.

\section{PRESENTATION OFTHE ASSESSMENT}

The videos prepared by students were presented in the class. Students were given 30 minutes to present their video output. At the end, I gave positive feedback as appreciation for admirable student work (Wang, Teo, \& Yu, 20 I7) and constructive feedback to further improve their work in the future. I found that the video presentation was a great learning activity for all students. It summed up student learning experiences and reflected on applications of the New Zealand Building Code (NZBC). This activity also developed students' capabilities such as working in teams, reflecting on performances, practicing health and safety and solving problems. I am planning to facilitate this activity in the future by incorporating peer suggestions for different groups so that student insights can also be incorporated in the feedback session.

\section{THEWAY FORWARD}

As a construction course facilitator, I believe that experiential learning and reflective practice promote effective learning. In my future teaching practices, I would like apply a combination of the experiential learning model introduced by Roberts (2006) and the pedagogical model of reflective practice for construction educators introduced by Kamardeen (2015).

According to the fourth pillar of this pedagogical model, assessments should be clear and transparent to students. The assessment methods used in construction management classes are varied and include reports, oral presentations, 
computer software based projects and exams. Having a variety of clear and transparent assessments benefits all students to utilise their specific strengths in different assessments (Sambell, McDowell, \& Montgomery, 2013). The marking and feedback provided by the facilitator should be fair, consistent, and transparent for the students. As encouraged by Sulton (1995), I will provide prompt feedback for students' assessments, and it will be used as a teaching tool for the class. Also, I will devote a portion of the lesson to look at draft submissions by the students. I hope that my feedback on the draft submissions would guide students towards improving their final submissions. In order to ensure the quality of the assessments, I will conduct quality checks (e.g. pre and post moderation) to ensure the assessment-alignment with the learning outcomes.

Self-reflection helps facilitator to understand the current practices of effective assessment process and identify areas for future development. However, facilitators need to understand that the implementation of effective assessments requires personal change in both students and facilitators (Moon, 2004). In other words, assessments for learning needs to engage in behaviour development through reflective practices (Black, Harrison, \& Lee, 2007). As per the Emotional Intelligence theory developed by Goleman (1995), the facilitator needs to slow down the pace of teaching and involve more emotion to make meaning out of experiences (Baldris, et al., 20 I6). I believe critical reflection would help me to bring effective assessment processes in my future teaching roles. It is important that I discuss and show examples of reflective activities in the class. For example, it would be a good practice to incorporate weekly reflective journals in my practice. Furthermore, when reflecting, the emotions that are associated with the learning activity must be taken into account (e.g., fear, panic hesitation, calm or elation). Thereby, meaningful discussions of students' conceptions of reflection would be generated. This would initially help students to be familiar with the reflective writing style. Afterward, I should enable practice and opportunities for feedback on students' reflective writing. I will then support students with further development of reflective writing with exercises and activities. For example, I am planning to set up forums and question and answer sessions on Moodle. This would help students share their ideas on reflective practices. In this process, I will have to prepare to support some students more than others as the reflective practices may be entirely new for some students. Eventually, both students and I would engage in reflective practices naturally. I hope that this approach would benefit us to firstly self-reflect on our learning and secondly use the selfreflective outcomes for learning through thinking.

\section{CONCLUSION}

The group video assessment based on a real construction experience was very effective due to its engaging and student-centered nature. It was primarily used as a learning tool rather than an assessment. The group work activities helped students to work in teams from the very beginning. It helped students to develop their skills and capabilities. This assessment experience also appeared to have created a cultural shift in learning which improved learning styles among students and had many positive impacts on my teaching practices. I discovered that students learn effectively and are engaged when their studies are linked with practical, experiential learning activities. It was evident that students appreciate the value of constructive feedback provided by the facilitator and their peers. The self-assessment helps to reinforce the external feedback and increase the quality of learning. As a result, my current class facilitations incorporated at least one practical, experiential learning activity (construction site visit, building surveying activity and visiting a construction expo) to make sure that my students were well engaged and made meaning from their learning.

The reflection processes embedded in my classes help students to solidify the new knowledge gained and new skills learned. Furthermore, it increases students' confidence to apply the newly acquired insights in similar and new situations. However, it is acknowledged that reflection is a challenging process to practice together with students in the class. Facilitators need to identify ways to encourage students' reflection. To begin with, the facilitator could take a few notes immediately at the end of the class about what worked or still could be improved. Even though reflection occurred as a natural phenomenon, usually, it is rarely brought up for critical discussions with students. Therefore, facilitators should review their teaching practice and improve the reflective activities in the curriculum delivery. It is suggested that rigorous, purposeful and goal oriented thinking needs to be incorporated into teaching practice so that the learning from reflections can be fed into delivery of effective assessments. 
Don Samarasinghe is very excited and passionate about teaching and researching in the built environment, with a strong desire for developing tertiary students and unleashing their potential. He has ten years of experiential learning and reflective practice based teaching experience in New Zealand tertiary education. His qualifications include a $\mathrm{PhD}$ in construction management, a graduate diploma in tertiary education, and a bachelor of civil engineering degree with first class honours.

\section{REFERENCES}

Assessment Reform Group. (1999). Assessment for learning: beyond the black box. Cambridge, England: University of Cambridge School of Education.

Baldiris Navarro, S., Zervas, P., Fabregat Gesa, R., \& Sampson, D. G. (2016). Developing Teachers' Competences for Designing Inclusive Learning Experiences. Journal of Educational Technology \& Society, 17-27.

Bell, R., Kāwharu, M., Taylor, K., \& Belgrave, M. (2017). The Treaty on the ground: where we are headed, and why it matters. Auckland, New Zealand: Massey University Press. 2017

Black, Harrison, C., Lee, C., Marshall, B., \& Wiliam, D. (2003). Assessment for Learning. Berkshire, England: Open University Press.

Black, P., Harrison, C., \& Lee, C. (2007). Assessment for Learning: Putting It into Practice. Berkshire, United Kingdom: McGraw-Hill Education.

Brookfield, S. (2005). The Power of Critical Theory for Adult Learning and Teaching. San Francisco, CA: Jossey-Bass.

Brookfield, S. D. (1995). Becoming a critically reflective teacher. San Francisco: Jossey Bass.

Burt, J. M., Donaldson, M. R., Hruska, K. A., Hinch, S. G., \& Richardson, J. S. (2012). Interactive Field Site Visits Can Help Students Translate Scientific Studies into Contextual Understanding. Visitas educativas en campo.

Carless, D., Salter, D., Yang, M., \& Lam, J. (20I I). Developing sustainable feedback practices. Studies in Higher Education, 395-407.

Elen, J., Clarebout, G., Leonard, R., \& Lowyck, J. (2014). Student-centred and teacher-centred learning environments: what students think. Teaching in Higher Education, I2(1), I05- I I 7. doi: I 0. I 080/ I 35625 I 0601 I 02339.

Faria, C. u., \& Chagas, I. (20I3). Investigating School-Guided Visits to an Aquarium: What Roles for Science Teachers? International Journal of Science Education, Part B, 3(2).

Goleman, D. (1995). Emotional intelligence. New York, NY, England: Bantam Books, Inc.

Ingalls, J. S. (20 8). Improvisational Theater Games: Performatory Team-building Activities. Journal of Physical Education, Recreation \& Dance, 89(I), 40-45. doi:10.1080/07303084.2017.1390507

Jasper, M., Freshwater, D., \& Rolfe, G. (20I I). Critical reflection in practice: generating knowledge for care. Basingstoke: Palgrave Macmillan.

Kamardeen, I. (20I5). Critical reflective pedagogical model: a pragmatic blueprint for enhancing learning and teaching in construction disciplines. Construction Economics and Building, 15(4), 63-75.

Lei, S. A. (2016). Assessment practices of advanced field ecology courses. Education, 132(2), I1 7 - I 22.

Lohmann, R. T. (1980). Planning Field Trips: A Check List. History News, 35(3), 44-44.

McLelland, G., McKenna, L., \& French, J. (20I3). Crossing professional barriers with peer-assisted learning: Undergraduate midwifery students teaching undergraduate paramedic students. Nurse Education Today, 33(7), 724-728. doi: I0. I0 I 6/j.nedt.20 I2.10.0 I6

Moon, J.A. (2004). A Handbook of Reflective and Experiential Learning:Theory and Practice. London, United Kingdom:Taylor \& Francis Ltd.

Nguyen, T.T. H., \&Walker, M. (20 I4). Sustainable assessment for lifelong learning. Assessment \& Evaluation in Higher Education, 4 I ( I), 97- | | I. doi: |0.1080/02602938.2014.985632

Roberts, T. G. (2006). A philosophical examination of experiential learning theory for agricultural education. Journal of Agricultural Education, 47(I).

Sambell, K., McDowell, L., \& Montgomery, C. (2013). Assessment for Learning in higher education. NY: Routledge.

Sulton, R. (1995). Assessment for learning. Sanford, United Kingdom: RS Publications.

Vassilakis, P. N. (20 I0). Assessment-Driven Collaborative Learning. College Music Symposium, 49/50, 207-2 I6. Retrieved from http:// www.jstor.org/stable/4I 225247 Paper presented at the College Music Symposium.

Wang, B., Teo,T., \& Yu, S. (2017). Teacher feedback to student oral presentations in EFL classrooms: a case study. Journal of Education for Teaching, 43(2), 262-264. 